811.163.41-112

811.163.41'342(091)

050.9:811.163.41'35(497.16)

https://doi.org/10.18485/sj.2020.25.1.32

\author{
ЈЕЛЕНА М. ГАЗДИТ \\ Оригинални научни рад \\ Универзитет Црне Горе \\ Примљен: 15. 10. 2019. \\ Филолошки факултет у Никшићу \\ Прихваћен: 15. 01. 2020. \\ Студијски програм за српски језик и јужнословенске књижевности
}

\title{
КОНТИНУАНТИ ВОКАЛА ЈАТ У АЛМАНАХУ ГРЛИЦА (1835-1839)
}

У вези са јатом у првом цетињском алманаху, обратићемо пажњу на континунате овог старог вокала. Представићемо графијска рјешења за обиљежавање рефлекса дугог и кратког јата и покушати да одредимо гласовне вриједности континуаната овог вокала, са освртом на јекавско јотовање и појаву секундарног јата.

Кључне ријечи: Грлица, јат, континуанти, ијекавски, екавски, икавски, рефлекс.

1. Први литерарни алманах на простору данашње Црне Горе покренут је на Цетињу средином четврте деценије 19. вијека на иницијативу младог владике Његоша. Како и сам уредник Грлище каже у предговору издања из 1835. године, овај годишњак угледао је свјетлост дана захваљујући Петру II Петровићу Његошу који је захтијевао да се „у овдашњој штампарији [...] наштампа календар за годину 1835" (Грлица 1835: 1). Издавање алманаха Његош је повјерио Мостарцу Димитрију Милаковићу르, изузетном интелектуалцу, лингвисти, историчару, човјеку широког образовања који је био познавалац

\footnotetext{
*jelena.gazdic@gmail.com

${ }^{1}$ О Милаковићевој биографији погледати детаљније код Шуковић 1980: 27-31; Магазин српско-далматински 1860. Једино је издање из 1837. године уређивао архимандрит Петроније Лујановић јер је Милаковић у то вријеме био у Русији (Шуковић 1980: 49).
} 
тадашњих збивања у области књижевности и језика, а и сам је говорио стране језике (Шуковић 1980: 21, 27). „Својом садржином ова периодична публикација одсликава друштвене и културне прилике у средини гдје је поникла, у њој се преламају књижевна струјања једног времена, а особито борба прогресивних друштвених снага, на челу са Вуком Караџићем, за препород културе и реформу књижевног језика" (Шуковић 1980: 21). Имајући у виду културно-историјске и језичке прилике у којима је настао и објављиван овај годишњак, онда је сасвим јасно да он представља изузетно значајан материјал за језичка истраживања и употпуњавање слике о развоју српског језика и штампе на територији данашње Црне Горе.

У овом раду осврнућемо се на вокал $\mathrm{j}^{2}{ }^{2}$ у првом цетињском алманаху ${ }^{3}$, при чему ћемо покушати да одредимо гласовне вриједности континуаната овог старог вокала и промјене које је условљавао. Као посебна фонема јат је био у употреби до 13 или 14 вијека, кад је почела његова замјена другим гласовним вриједностима. У вријеме излажења Грлище јат је увелико био прешао у своје рефлексе. ${ }^{4}$ Ми ћемо у овом раду вршити поређење са Вуковим језиком, а уколико нам то околности намећу, и са дијалектима оних говорних подручја српског језика из којих су били сарадници Грлице (Петар I Петровић Његош, Петар II Петровић Његоша, Георгије Петровић Његош, Сима Милутиновић Сарајлија, Георгије Николајевић, Димитрије Милаковић (Шуковић 1980: 31, $32)^{5}$, као и са језиком старијих писаца и сарадника Грлице чији је језик већ

${ }^{2}$ „Вокал ъ представља једну од најсложенијих фонематских јединица у вокалском систему не само прасловенског већ и у историји српског језика, прво: зато што не знамо његову основну гласовну вриједност, друго: што су се његове измјене у различитим крајевима извршиле у различито вријеме, па у писаним споменицима у прелазним подручјима наилазимо и на њихово мијешање; најзад: зато што имамо различите гласовне фонематске замјене прасловенског јата како у свим словенским језицима тако и у српском језику” (Стојановић 2005: 82). Мишљења лингвиста су подијељена у вези са гласовном вриједношћу овог старог вокала, али је код нас углавном прихваћена Белићева теза - да је јат био неправи и непотпуни дифтонг који је имао двије варијанте са два дијела, са првим отворенијим и другим затворенијим - ë̈, іё (Белић 2006: 81).

${ }^{3}$ У издањима из $1835,1836,1837$. и 1838 . нумерацију смо започели од предговора, а у издању из 1839. од садржаја.

${ }^{4}$ Досадашња истраживања су показала да су замјене јата са $е$ и $u$ старије од ијекавског рефлекса (Детаљније о овоме Белић 2006: 83).

${ }^{5}$ Осим прилога наведених аутора, Шуковић тврди да је у Грлици објављено и неколико народних епских пјесама (Шуковић 1980: 31, 32). Мишљења научника у вези са сарадницима овог алманаха донекле су различита. Т. Ђукић у Прегледу књижевног рада Црне Горе од владике Василија до 1918. године, Цетиње 1951, као сараднике наводи Петра І Петровића Његоша, Петра II Петровића Његоша, Симу Милутиновића и Димитрија Милаковића. Нико С. Мартиновић у књизи Развитак штампе и итампарства у Црној Гори (1493-1945), као сараднике Грлице помиње Димитрија Милаковића, Петра II Петровића Његоша (под псеудонимом Драго Драговић), Симу Милутиновића, Георгија Николајевића (под псеудонимом Г. Н.) и друге. У Југословенском књижевном лексикону (Нови Сад, 1971), као сарадници овог алманаха наведени су Сима Милутиновић, Петар II Петровић Његош и Димитрије Милаковић. 
био предметом научних истраживања (овдје првенствено мислимо на Петра I и Петра II Петровића Његоша).

\section{2. КОНТИНУАНТИ ДУГОГ ЈАТА}

\section{1. У прва три издања Грлице рефлекс дугог јата већином је означаван} секвенцом $i \epsilon^{6}$, уз извјесна одступања на која углавном наилазимо у текстовима јединог сарадника Грлище који је био екавац по рођењу - Георгија Николајевића ${ }^{7}$ У посљедња два издања овог алманаха обиљежавање дугог јата је неуједначено. Наиме, у издању из 1838. на мјесту некадашњег дугог јат пишу се секвенца $i \epsilon$, вокал $e$, или веома често $b$. У издању из 1839 . године као графијска рјешења срећемо јат и вокал $e$. Примјере ћемо класификовати с обзиром на графијске ознаке:

раздієлиле (Г. 1835: 4), иієлой (Г. 1835: 30), свієт (Г. 1835: 70), бієло (Г. 1835: 100), лієк (Г. 1835: 126), одієло (Г. 1835: 44), врієме (Г. 1835: 22, 23, 24, 49, 65), рієке (Г. 1835: 66), врієђати (Г. 1835: 99), бієло (Г. 1835: 100), вієка (Г. 1835: 107), свієст (Г. 1835: 108), мієнямо (Г. 1835: 112), стрієлах (Г. 1835: 123), дієте (Г. 1835: 124), вієка (Г. 1835: 129), приповієдка (Г. 1836: 3), изнайпріє (Г. 1836: 25), снієе (Г. 1836: 21, 26), врієме (Г. 1836: 23, 24, 51), запрієтили (Г. 1836: 50), мієшати (Г. 1836: 51), свієтлом (Г. 1836: 78), бієла (Г. 1836: 85), умрієти (Г. 1836: 71), бієлой (Г. 1836: 77), вієк (Г. 1836: 83), уиієнбна (Г. 1836: 67), лієвой (Г. 1836: 69), рієч (Г. 1836: 78, 83 91), сієчете (Г. 1836: 47), раздієлиле (Г. 1837: 34), приповієдке (Г. 1837: 3), посієкоше (Г. 1837: 60), свієту (Г. 1837: 76), лієпа (Г. 1837: 19), врієме (Г. 1837: 19, 20, 22, 37, 81, 139), умрієт (Г. 1837: 58), проповієд (Г. 1837: 77), понієли (Г. 1837: 74), помрієще (Г. 1837: 74), попрієко (Г. 1837: 86), рієтко (Г. 1837: 87), свієт (Г. 1837: 133), слієп (Г. 1837: 134), бієлу (Г. 1838: 79, 101), лієпа (Г. 1838: 110), свієће (Г. 1837: 112), сієно (Г. 1838: 112), свієту (Г. 1838: 118);

бела (Г. 1835: 123), речма (Г. 1835: 124), редко (Г. 1835: 127), корень (Г. 1836: 113), вредни (Г. 1836: 115), време (Г. 1836: 119), свеће (Г. 1837: 99), заслепльни (Г. 1837: 100), стрелу (Г. 1837: 100), пресече (Г. 1837: 106), умрети (Г. 1837: 121), умрети (Г. 1838: 22), време (Г. 1838: 23, 24, 25, 43, 69), брега (Г. 1838: 94), време (Г. 1839: 20, 21, 22, 25), найпре (Г. 1839: 21, 23, 47), умрети (Г. 1838: 93), звездама (Г. 1839: 108), увекъ (Г. 1839: 110);

Заповъди (Г. 1835: 60, глагол), посль (Г. 1835: 20), иълога (Г. 1836: 108), дъте (Г. 1836: 109), съде власи (Г. 1835: 116), посъче (Г. 1835: 47), иъли (Г. 1837: 96), исповъдити (Г. 1837: 97), тълу (Г. 1837: 104), преповъдао (Г. 1837: 106), примътити (Г. 1837: 107), гръхе (Г. 1837: 115), промъни (Г. 1837: 117), заповъсть (Г. 1837: 118), посъкоме (Г. 1837: 82, 83), свъта (Г. 1837: 123), стрбле (Г. 1837: 124), кръпког'(Г. 1837: 124), въние (Г. 1837: 127), дъте (Г. 1837: 128), снъгь (Г. 1838: 23), льпо (Г. 1838: 24), раздълиле (Г. 1838: 4), иъла (Г. 1838: 22), заповъдь (Г. 1838: 40, 51), найпослъ (Г. 1838: 37, 41), послъ (Г. 1838: 46, 54),

${ }^{6}$ У издањима из 1835. и 1837. срећемо и три примјера у којима је дуго јат означено секвенцом іе: посіеку (Г. 1835: 37), двіе (Г. 1835: 51), уніела (Г. 1837: 57).

${ }^{7}$ Георгије Николајевић (1807-1896) је био српски теолог и митрополит дабробосански. Рођен је у селу Јаску (Срем) 1807. године као Ђорђе Николајевић. Основну школу је завршио у родном селу. Од 1817. до 1819. године ишао је у њемачку школу у Митровици, послије тога уписује гимназију у Сремским Карловцима, а потом Богословију (Шуковић 1980: 44; Георгије Николајевић (1807-1896). Рођење, школовање, рад и рукоположење, http://www. mitropolijadabrobosanska.org/georgijenikolajevic.html, преузето 7.6.2015). 
пресъку (Г. 1838: 53), исповъданія (Г. 1838: 67), предъль (Г. 1838: 68), разсъћи (Г. 1838: 87), раздылиле (Г. 1839: 2), снъгомъ (Г. 1839: 20), посль (Г. 1839: 20, 23, 24), иълога (Г. 1839: 38), заповъдаюћи (Г. 1839: 63), заповъди (Г. 1839: 63), лъвогъ (Г. 1839: 67), въка (Г. 1839: 69), иълу (Г. 1839: 90), извъстити (Г. 1839: 91), иъломъ (Г. 1839: 96), преповъдити (Г. 1839: 92), преповъдати (Г. 1839: 99).

С обзиром на то да је Грлица штампана на ијекавском говорном подручју и да су њени сарадници углавном били ијекавци, гласовна вриједност секвенце $i \epsilon$ несумњиво је ијекавска у примјерима у којима је некада било дуго jam. Примјери са графемом е потврђени су у пјесмама Симе Милутиновића Сарајлије и у прилозима Георгија Николајевића и Димитрија Милаковића, ${ }^{8}$ a означавали су екавске рефлексе јата. Проблем нам пак представља одређивање гласовне вриједности самог јата у овој позицији. Примјере са јатом налазимо код Петра I Петровића Његоша, Петра II, Милаковића, Георгија Николајевића, ${ }^{9}$ као и у календарском дијелу Грлище и у рубрици Календарско погађанъ (с тим што је у овој рубрици јат писано само у посљедња два издања).

У вези са гласовном вриједношћу јата код уредника првог цетињског алманаха, Ћупић каже сљедеће: „Милаковић је по рођењу ијекавац. Његова ијекавштина је истог оног типа коју је срео на Цетињу. Но, изузетно се код њега срећу и екавизми [...] и икавизми [...], што може да буде и морфолошког карактера [...]" (Һупић 1982: 272). Ћупић даље појашњава да се еквизми типа унапред и време код Милаковића срећу углавном након његове једногодишње паузе у уређивању и по повратку из Русије, наравно, уз појединачне изузетке и од раније, и истиче да због тога „не можемо у потпуности бити сигурни у вриједност јата у примјерима из Грлице какви су: въра (I, 48), мъсто (I, 56), $6 z x y$ (I, 60, 62, 63 итд., односно досљедно тако у свим годиштима), побъга (I, 69, нап.), укльве (I, 45, 49), испоганън (I, 48), нъга (I, 57), нъговієма (I, 62); намъравао (I, 86), мъстима (I, 47, 64), слъдујуће (I, 42), съо (III, 47), прольћа, убъђени, сътовао (III, 44). [...] У свим случајевима са знаком $b$ гласовна вриједност јата може бити двојака - јекавска и ијекавска. Међутим, све те случајеве ми морамо сматрати јекавским" (Ћупић 1982: 272). Ту у фусноти Ћупић тврди да „у складу са рускословенском ортографском нормом знак $b$ овдје означава секвенцу је (Ћупић 1982: 272, фуснота 23). Мало даље он каже да су и бројни примјери јекавског јотовања доказ да „знак $b$ код Милаковића има вриједност je" (Һупић 1982: 273). Међутим, Ћупић превиђа да се након повратка из Русије код Милаковића поред екавизама интензивније почиње писати јат и на мјесту некадашњег дугог јата, што додатно компликује ситуацију при одређивању гласовне вриједности овог старог вокала у цетињском алманаху.

\footnotetext{
${ }^{8}$ Упоредити са Грлица $(1835,1836,1837,1838,1839)$ и Шуковић 1980: 48-54.

${ }^{9}$ Грлица (1835-1839); Шуковић 1989: 48-54.
} 
Како бисмо дату проблематику боље разумјели, неопходно ју је сврстати и у одговарајући историјскојезички контекст. Наиме, познато нам је да око 1730. године долази до великог преокрета и до смјене редакција црквенословенског језика. Код Срба је то један од највећих преокрета у историји српског књижевног и црквеног језика. Друштвени и историјски разлози условили су прихватање рускословенског језика чији се изговор одликовао јекавизмом, што је био заокрет у односу на екавску традицију српскословенског (а разликовало се и са стањем у било ком говору срп. језика). Након тога долази период славеносрпског (чија је основа била екавска), састављеног од српског народног (најчешће шумадијско-војвођанског), рускословенског, затим од ондашњег руског књижевног и од српскословенског... „То је отворило простор и довело до стварања више различитих континуаната за јат везано за различите функционалне стилове [...] Због тога се у предвуковском периоду појавила неуједначеност што се тиче писања и изговора континуаната за вокал јат (Стојановић 2007-2008: 310).

О писању јата на ијекавском подручју српског језика тог времена код проф. Стојановић налазимо: „За ијекавски простор (односно писце који су стварали на ијекавској подлози) карактеристична је већа неуједначеност: чување јата, замјена (и)јекавским рефлексом, замјена екавским рефлексом (екавизми су или из говора писца, што је рјеђе, или, што је чешће, књишког поријекла: утицај црквенословенског или славеносрпског). Ово се очитује у нпр. дјелима Василија Петровића, Петра I, Његоша: - дакле, прије свега налазимо (и)јекавски рефлекс, затим екавизме који су присутни у говорној средини" (Стојановић 2007-2008: 311).

Управо овакво неуједначено стање одликује и језик Милаковићеве Грлице који је у основи био народни са извјесним примјесама рускословенског и руског, а „можда и нешто славеносрпског.” [...] То је, ако смијемо слободно рећи, у неку руку посебан Милаковићев језик, доста близак Вуковом, али у понечему и различит од њега. У главним цртама, Милаковићев језик је исти као језик Петра I Петровића, што, свакако, значи да је близак и Његошевом" (Ћупић 1982: 269). Према томе, можемо закључити да је овакво неуједначено писање рефлекса дугог јат условљено утицајем језика цркве (нарочито у посљедња два издања) и дијалектаске базе, као и да је производ утицаја различитих „стилова”. У издањима из 1838. и 1839. заправо ова графема има ортографско-историјску функцију, а њену гласовну вриједност треба тражити у претходним издањима (нарочито у прва два).

Овдје треба предочити и још један важан детаљ који је могао утицати на писање jата у посљедњим издањима. То што у посљедња два издања уредник Милаковић враћа елиминисане знаке без гласовне вриједности Шуковић доводи у везу са „снажним отпором православне цркве и протестом званич- 
не Србије (у којој је тих година Вуков правопис и званично забрањен) због правописних измјена у цетињским издањима" (Шуковић 1987: 39). О томе свједочи и писмо у којем је српски кнез Милош прекорио владику Његоша због ортографије у издањима цетињске штампарије, истакавши да је то „противно правилима ортографије књигопечатани црковни словенски књига нашег вјероисповједанија" (Његош 1974: 57). Његош је српском кнезу одговорио 1837, пославши писмо из Беча у којем је „изразио жељу за заједничким правописом и нормом" (Шуковић 1987: 39).

2.2. Осим наведених примјера, у вези са дистрибуцијом дугог jama//u пажњу треба посветити и категорији морфолошког уједначавања старе тврде основе (са тематским вокалом jam) и меке (са тематским вокалом $u$ ) замјеничко-придјевске деклинације. У књижевном језику је преовладала употреба меке варијанте, тако да се облици са тематским вокалом $u$ узимају као нормативни, док је ситуација у дијалектима разнолика. У Милаковићевој Грлици долази до колебања између наставака тврде и меке промјене, што показују примјери који слиједе.

слободним лищем украшене (Г. 1835: 118), с превисоком (Г. 1836: 69), съ коимъ (Г. 1839: 59), са своимъ мачемъ (Г. 1837: 94), съ другимъ оддъленіємъ (Г. 1838: 52), незавоеванныхъ (Г. 1835: 69), Черногорскихъ Сербовъ (Г. 1838: 2), своихъ (Г. 1839: 97), Красныхъ (Г. 1839: 120); ніє било никаквіе школа, у коима би се младеж могла учити (Г. 1835: 46), праћени пуцнявом топова [...], на коима су се Русски баряци віяли (Г. 1837: 40), О свътскима стварма могло би се доста коєшто рећи (Г. 1838: 19), разиду се по своимъ домовима (Г. 1838: 40), покрывенъ льпима шумама (Г. 1839: 39), писати писма иностранымма Дворовима (Г. 1839: 68), тиняше у ньиовимъ прсима (Г. 1837: 95);

с такієм народом (Г. 1835: 56), с веселієм срием (Г. 1836: 60), стрменитієм брієгом (Г. 1837: 46), пред самієм важнісм пунктом (Г. 1835: 46), онієм великієм ударом збунъна (Г. 1837: 74), мене учини главнієм учительм (Г. 1837: 92); од Зетскієх и Црногорскієх Княжевах (Г. 1835: 51), насилнісхъ (Г. 1836: 64), великієх чудесах (Г. 1837: 72), своиєх (Г. 1837: 82), изъ ониехъ (Г. 1839: 1), їређашниехъ времена (Г. 1839: 86), нашиехъ времена (Г. 1839: 87), изъ мутниехъ очію (Г. 1839: 93), с превеликієма голієма стієнама (Г. 1835: 39), с коієма ће он въчни мир [...] утврдити (Г. 1836: 40), с веселієм срцем свак обећа (Г. 1836: 60), намъстіо се біо на неприступачнієм каменитієм висинама Дубровачкієма (Г. 1837: 45).

У неколико примјера имамо напоредо употријебљене наставке тврде и меке замјеничко-придјевске деклинације:

великим крвавісм зносм (Г. 1835: 115), Седамъ ћесахъ своихъ готовісхъ (Г. 1838:

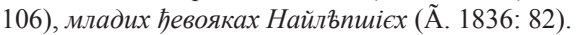

Примјећујемо да у Грлиции влада неуједначено писање наставака тврде и меке замјеничко-придјевске деклинације. Колебања су присутна и у оквиру истог текста. Рецимо у издању из 1835 . године у тексту уредника Милаковића Кратак поглед на географическо-статическо описаніє Црне Горе имамо и примјере са наставцима меке основе и примјере са наставцима тврде основе - у коима (Г. 1835: 46), на своима плећима (Г. 1835: 50) : у коієма (Г. 1835: 
39). Исти је случај и у издању из 1837 . године, гдје такође у тексту уредника долази до колебања - на коима (Г. 1837: 40), у ново покоренима земляма (Г. 1837: 41), овима окруженіяма (Г. 1837: 43) : на неприступачнієм каменитієм висинама (Г. 1837: 45). Важно је нагласити и да у приповијеткама (Милоє Цветићь, Изисъ и Тира, Калло) Г. Николајевића знатно преовладава употреба наставака меке промјене.

У прва два издања, без обзира на ауторе текстова, много су учесталији наставци тврде промјене, а у посљедња два наставци меке промјене, док у издању из 1837. године (које је уређивао архимандрит Петроније Лујановић) долази до колебања и неуједначености наставака. Ово је нарочито занимљиво ако узмемо у обзир да су код Вука облици са $u$ били чешћи до 1836. године, након чега преовлађују они са групом ије (Стевановић 1965: 210). Закључци до којих смо дошли не подударају се са тврдњом Д. Ћупића да је у језику Милаковића у замјеничко-придјевској деклинацији рефлекс јата двосложан и да је тако и у свим осталим радовима уредника првог цетињског алманаха, уз понеке изузетке (Ћупић 1982: 272, 273). Не можемо се сагласити са овом констатацијом, будући да смо у Милаковићевим текстовима запазили и примјере са наставцима меке промјене. И у говорима данашње Црне Горе стање је неуједначено - рецимо, у говорима новоштокавског типа у инструменталу једнине може се говорити о напоредној употреби дужих и краћих наставака, мада Пецо за говоре источне Херцеговине констатује само дуже облике. „Сличне оцјене могу се изрећи и за неке црногорске говоре зетско-јужносанџачког типа: материјал из говора Паштровића показује занемарљиво мали број примјера са краћим облицима, док се у Црмници, за ријетке примјере са наставцима старих меких основа [...] мисли да су несумњиво унесени са стране" (Јовановић 2011: 132). Стање у нашој Грлиции највише одговара језику Петра I гдје се напоредо јављају наставци меке и тврде промјене замјеничко-придјевске деклинације, с тим што су облици с двосложним рефлексом јата бројнији, а такви облици су уопштени и у говору Петрова краја, тј. у говорима Старе Црне Горе (Остојић 1976: 91, 93).

2.3. Код одричног помоћног глагола нијесам/нисам у Грлици напоредо срећемо примјере са двосложним рефлексом јата као и примјере са $u$. Дужи облици се јављају у прва два издања, а краћи у посљедња два, док у издању из 1837. године наилазимо на обје варијанте овог глагола ${ }^{10}$ :

Нієсмо (Г. 1835: 70), нієсам (Г. 1837: 73, 79), нієсмо (Г. 1837: 92), нієсмо (Г. 1837: 81); нисамъ (Г. 1837: 115), нису (Г. 1838: 39), ни су (Г. 1839: 50), нису (Г. 1839: 58).

${ }^{10}$ Примјери у којима је у издању из 1837. наведена дужа варијанта глагола нисам/нијесам су из Његошеве приповијетке Житіє Мрђена Несретниковића, а примјери у којима је писана краћа варијаната су из приповијетке Ізисъ и Тира, аутора Георгија Николајевића (Шуковић 1980: $52)$. 
Професор Остојић у језику Петра I наводи само дуже облике (Остојић 1976: 80). Краће варијанте у Грлиции су потврђене код Георгија Николајевића, који је по рођењу екавац из околине Срема. И проф. А. Милановић у језику Јована Суботића (који је такође Сремац) биљежи „икавски” рефлекс у одричном облику помоћног глагола јесам, што карактерише и ,језик књижевних дела Суботићевих савременика" (Милановић 2014: 91). Код Вука срећемо оба облика (Барјактаровић 1965: 18, 19, 20), као и облик несам који се може наћи у другом издању Вуковог Српског рјечника, „где се 'источно' (екавско) несам упућује на ијекавско нијесам (Младеновић 1983: 62). У данашњем књижевном српском језику оба ова облика су прихваћена, док је ситуација у дијалектима нешто другачија. Професор Јовановић истиче да се на простору Црне Горе стабилизовао двосложни рефлекс ије а да је аналошки облик са $u$ више везан за простор централне Херцеговине, с тим што „посебност неких црногорских говора чини развитак вокала $e$ " (Јовановић 2011: 96).

\section{3. КОНТИНУАНТИ КРАТКОГ ЈАТА И НАПОМЕНЕ О ЈЕКАВСКОМ JOTОВАњУ}

3.1. Познато је да је кратко јат на ијекавском простору прешло у је (негдје од краја 14. вијека, отприлике кад је и дуго јат прешло у своје рефлексе). Надосљедно се вршило и јотовање сугласника и сугласничких група испред je од кратког јата, а ова измјена неједнако је захватила ијекавске говоре. ${ }^{11}$

3.2. Ситуација није једноставна за анализу будући да нису коришћење посебне графеме за означавање фонема $s, b$. Слично је и у језику Петра I (Остојић 1976: 122), као и у Паштровским исправама у којима такође нису постојале посебне графеме за $љ$ и $ь$ (Стојановић 2011: 112). Начин биљежења у случајевима када је у питању нпр. прасловенско јотовање сонаната $л$ и $н$ може нам донекле послужити да одредимо процесе и појаве у вези са овом проблематиком [измиильна (Г. 1835: 4), боль (Г. 1835: 2, 62), ранъніс (Г. 1837: 43)]. Такође, имамо јасно разграничене именице са црквенословенским суфиксом -ије који се скоро досљедно означавао са іє [положителніє (Г. 1835 : 47)] за разлику од бројних глаголских именица изведених народним суфиксом -ъе у којима је извршено ново јотовање и у којима је секвенца ње означена са нъ [ученъ (Г. 1835: 46), крштенъ (Г. 1835: 53)]. На основу тога могли бисмо закључити да је и у примјерима са $ת, H+$ кратко јат извршено јекавско

${ }^{11}$ „О времену вршења јекавског јотовања не може се са сигурношћу говорити, с једне стране због недовољности споменичке грађе и непотпуне истражености, а, с друге стране, због графијски јасно недиференцираног биљежења палаталних сугласника, тј. непостојања графема за $\_, \preccurlyeq, \hbar$ и $\hbar$. [...] Углавном се за почетак јекавског јотовања узима период краја 16. и почетка 17. вијека" (Стојановић 2011: 112). 
јотовање, као и на основу тога што је Грлица штампана на (и)јекавском говорном подручју и што су скоро сви њени сарадници били ијекавци по рођењу, изузев Георгија Николајевића. У прилог томе иде и већ навођено мишљење Драга Ћупића који у раду Језик Димитрија Милаковића у „Грлиции” - првом црногорском кьижевном алманаху (1835-1839) ${ }^{12}$ каже да је вриједност јата у Милаковићем језику је, као и да је јекавско јотовање „углавном досљедна појава (изузимајући јотовање сугласника с и з)” (Ћупић 1982: 273, 275). Ипак, дилему ствара неуједначен начин писања рефлекса дугог јата иза л и н. Као што смо већ поменули, наспрам континуаната старог дугог вокала jam забиљежили смо облике са јатом (у посљедња три издања), затим облике са $e$ и веома ријетко са $i \epsilon$.

Кад су у питању рефлекси кратког јата послије сонаната л и $н$, у нашој грађи преовладавају примјери у којима је jam писано након ових фонема:

лъпоти (Г. 1835: 26), кольна (Г. 1835: 43), прольћу (Г. 1836: 20), льто (Г. 1836: 6), льпшу (Г. 1836: 87), лъвшіс (Г. 1836: 96), убольла (Г. 1837: 80), стольтія (Г. 1837: 107), одольи (Г. 1837: 135), льтописи (Г. 1838: 2), льпоти (Г. 1838: 65), льшницьі (Г. 1838: 66), льтне (Г. 1838: 84), льпотице (Г. 1838: 90), кольна (Г. 1839: 70), преодольти (Г. 1839: 90), хльба (Г. 1839: 99), преодольла (Г. 1839: 100); нъговали (Г. 1835: 127), нъдра (Г. 1835: 67), нъдра (Г. 1836: 91), нъжности (Г. 1836: 114), слабонъжногъ (Г. 1837: 118), нъдарах (Г. 1837: 134), нъжне (Г. 1837: 134), нъдра (Г. 1838: 83), нъжности (Г. 1838: 95), нъдро(а) (Г. 1839: 76, 79), снъљжииа (Г. 1839: 78), нъжнио (Г. 1839: 114);

Будући да је jam коришћено и у неетимолошким позицијама у гласовној вриједности је, 'e - иза л и н у гласовној вриједности $љ$ и н [измишлъна (Г. 1835: 4), проклинянъ (Г. 1839: 100)], то може бити показатељ палаталног изговора и сугласника $л$ и н у наведеним примјерима у којима је јатом писано на мјесту некадашњег кратког јата. Ријетки су примјери у којима је у овој позицији писано іє или е: найлієпше(а) (Г. 1837: 105, 115), найлієпши (Г. 1837: 95), Лешкопольци (Г. 1835: 104), пролеће (Г. 1837: 103).

3.3. Групу сл + в налазимо у великом броју примјера и досљедно је писана са јатом:

Сльдуюће (Г. 1835: 38), Посльдня (Г. 1835: 6), Наслвдникъ (Г. 1835: 27), слвдовао (Г. 1835: 52), посльднъга (Г. 1836: 69), Наслъдникъ (Г. 1836: 27), наслъдница (Г. 1836: 29), слъдуюће (Г. 1836: 38), послъдня (Г. 1837: 21-2), насльдница (Г. 1837: 29), слъдствію (Г. 1837: 38), напослъдку (Г. 1837: 78), посльдна (Г. 1838: 22), насльдникъ (Г. 1838: 31), насльдньій (Г. 1838: 31), сльдовала (Г. 1838: 51), послнасльдствено (Г. 1838: 85), посльдня (Г. 1839: 4), наслъдникъ (Г. 1839: 28), наслъдньімъ (Г. 1839: 29), сльдовательно (Г. 1839: 37).

Ћупић овакве примјере третира као јотоване (Ћупић 1982: 275). Начин биљежења ових секвенци у нашем корпусу дјелимично одудара од стања у

${ }^{12}$ У овом раду Ћупић је изучавао само језик прилога које је у Грлици писао Милаковић. 
језику Петра I, ${ }^{13}$ као и од стања у Паштровским исправама, ${ }^{14}$ што говори о већем степену уједначености. Из приложеног се види да се о писању ових група водило рачуна - да је у питању нека врста норме. Вук у „Преписци - и то у писмима која су писана ијекавски" - користи и еквизме типа последњи (Пецо 1965: 193).

3.4. Прилог (нај)послије писан је на више начина - са јатом, са $е$ и са $i \epsilon$ (с тим што је у овом посљедњем случају - $\partial$ на крају ријечи):

послъ (Г. 1836: 20), посль (Г. 1838: 3), найпослъ (Г. 1838: 19), посль (Г. 1839: 19), посль (Г. 1837: 37), найпосль (Г. 1837: 48) найпосле (Г. 1836: 50), после (Г. 1839: 115), найпосле $\left(\right.$ Г. 1839: 89, 95) ${ }^{16}$; послієд (Г. 1837: 72), найпослієд (Г. 1837: 85) ${ }^{17}$.

У Паштровским исправама овај прилог се првенствено јавља у форми са -ије (Стојановић 2011: 116), у језику Петра I посвједочени су екавски и много чешће ијекавски облици (Остојић 1976: 86), код Његоша Вушовић биљежи примјера са ије(д) и је (Вушовић: 10, 11), док Пецо биљежи да је „Вукова писана ријеч” знала и за „извјестан број еквизама” међу које убраја и лексему после (Пецо 1965: 193). Према томе, и језик наше Грлице се уклапа у историјскојезички контекст и подудара се са стањем у језику писаца који су стварали тридесетих година 19. вијека на ијекавском говорном подручју.

3.5. Неодређене замјенице и прилози у овом дијелу нашег корпуса скоро досљедно су писани у нејотованој форми, тј. са вокалом е [неколико (Г. 835/46), неке (Г. 1835: 93), некоєга (Г. 1835: 57), неколико (Г. 1836: 53, 111), неколико (Г. 1837: 74, 121), некоме (Г. 1837: 93), неколико (Г. 1838: 57, 64), понеколико (Г. 1838: 71), неколико (Г. 1839: 52)]. Занимљиво је да примјере са јатом налазимо код сарадника који је по рођењу екавац - Георгија Николајевића (у приповијеци Ізисъ и Тира): нъко (Г. 1837: 97), нъкогъ (Г. 1837: 120). Такође, ни Вук у вријеме излажења Грлице није употребљавао јотоване форме ових категорија, ${ }_{18}^{18}$ иако је то особина неких говора Црне Горе. ${ }^{19}$ Јотовани облици коришћени су у језику Петра I (Остојић 1976: 122), код Његоша ријетко (Вушовић 1930: 11).

\footnotetext{
${ }^{13}$ Код Петра I потврђени су облици са $e$ (чији изговор може бити и екавски и ијекавски) и са јатом (који су јотовани) (Остојић 1976: 122).

${ }^{14}$ У Паштровским исправама примјери са секвенцом сл су различито писани са јатом и са $e$, а срећу се и форме са иле и иль (Стојановић 2011: 115, 116 ).

${ }^{15}$ Прва четири примјера су из календарског дијела Грлище 1836, 1838, 1839, а преостали примјери су из одјељка чији је аутор Милаковић (Шуковић 1980: 48-53).

${ }^{16}$ Примјери су из одјељака чији су аутори Милаковић, Његош и Георгије Николајевић (Грлица 1836: 37-50; Грлица 1839: 85-114; Шуковић 1980: 48-53).

${ }^{17}$ Оба примјера су из Његошеве приповијетке Житіє Мрђена Несретниковића (Упор. Шуковић 1980: 48-53).

${ }^{18}$ Отприлике од 1839. до 1845. године Вук је давао првенство јотованим облицима (Стевановић 1965: 214).

${ }^{19}$ Упор.: Милетић 1940: 372; Вујовић 1969: 188, 189.
} 
3.6. Консонанти $m$ и $\partial$ касније су захваћени јекавским јотовањем у односу на $л$ и н. „Због тога је ова појава територијално ограниченија, а и процес се није вршио доследно у свим позицијама као код $л$ и $\mu$. Први примјери пронађени су у писаним документима из 16. вијека" (Стојановић 2011: 116J). Јотоване форме сугласника $m$ и $\partial$ у нашем корпусу означаване су графемама $\hbar$ и $\hbar .{ }^{20}$ Ове двије графеме досљедно се употребљавају у Грлици. Вук их пише у свом рјечнику из 1818. године, мада је $\hbar$ и раније употребљавао (Симић 1991: 259). Драго Ћупић наводи само јотоване облике у Милаковићевом језику (Ћупић 1982: 275). Међутим, ми смо у овом цетињском алманаху (укључујући и Милаковићеве прилоге) забиљежили и јотоване и нејотоване облике, а овом приликом навешћемо само по неколико из свих бројева:

кћели (Г. 1835: 46), ћераю (Г. 1835: 56), поћерало (Г. 1835: 129), некћеше (Г. 1835: 68, 69), проћерати (Г. 1836: 52), ућера (Г. 1836: 70), нећера (Г. 1836: 89), улећело (Г. 1836: 94), Некћеше (Г. 1837: 54), разћераше (Г. 1837: 84), полећело (Г. 1837: 72), ошћело (Г. 1837: 81), оћера (Г. 1838: 115), полећеле (Г. 1838: 118), нехће (Г. 1838: 108), исћера (Г. 1838: 109), ћеду (Г. 1839: 89), разћерала (Г. 1839: 96), ћераю (Г. 1839: 108); Вићеће (Г. 1835: 26), виђеше (Г. 1835: 85), Ђеиа (Г. 1835: 108), Һеиу (Г. 1835: 88), посиђе (Г. 1835: 128), невиђелом (Г. 1835: 129), понеђельник (Г. 1836: 6), Ђеиу (Г. 1836: 84), виђеће (Г. 1836: 89), виђела (Г. 1836: 93), ђевояках (Г. 1836: 87), Ђевера (Г. 1836: 95), неђель (Г. 1837: 6), зађедоме (Г. 1837: 50), невиђела (Г. 1837: 58), међеди (Г. 1837: 135), неђелю (Г. 1838: 100), неђеля (Г. 1838: 103, 104), неђельица (Г. 1838: 105), виђети (Г. 1838: 101), Ђевойку (Г. 1838: 111 Ђевойка (Г. 1838: 114), неђеля (Г. 1839: 94);

утвиио (Г. 1835: 122), утвиити (Г. 1836: 115), твлеса (Г. 1836: 80), утвха (Г. 1837: 127), утъшен (Г. 1837: 128), тълесним (Г. 1837: 129), Утъхою (Г. 1838: 2), тъиећи (Г. 1839: 112), хтъли (Г. 1838: 39), хтъла (Г. 1838: 40), Нехтъдну (Г. 1839: 66), тълесногъ (Г. 1839: 109); дъчииа (Г. 1835: 122), дъиа (Г. 1835: 127), дълам (Г. 1835: 53), раздълюе (Г. 1835: 38), дъиа (Г. 1836: 128), дъло (Г. 1836: 126), дъие (Г. 1837: 95), дълима (Г. 1837: 88), дъвойчииа (Г. 1837: 115), дътића (Г. 1837: 105), дъвице (Г. 1837: 112), видъти (Г. 1838: 21), дъла (Г. 1838: 52), дъвойчица (Г. 1838: 73), недълую (Г. 1838: 79), дъла (Г. 1838: 92), недъля (Г. 1839: 4), дъиа (Г. 1839: 18), дълама (Г. 1839: 51), обдълали (Г. 1839: 51), злодвланіс (Г. 1839: 104), дъчице (Г. 1839: 106), дъиу (Г. 1839: 113), дътенце (Г. 1839: 113), одъвена (Г. 1839: 117).

У Грлици је ситуација неуједначена у вези са јекавским јотовањем сугласника $m$ и $\partial$, чиме се језик овог алманаха донекле поклапа са језиком Петра $\mathrm{I}^{21}$ и језиком Петра $\mathrm{II}^{22}$ а дјелимично се разликује од стања у говорима данашње Црне Горе ${ }^{23}$ и у Памтровским исправама ${ }^{24}$.

${ }^{20}$ Преглед графематских рјешења за фонеме $\hbar$ и $\hbar$ у предвуковском периоду погледати у Херити 1983: 48-50.

${ }^{21}$ „У језику Петра I не налазимо потпуно стабилизовану ситуацију ни у вези са најновијим јотовањем сугласника: $m, \partial$, л, н...” (Остојић 1976: 121). Наиме, $m$ се по правилу јотује, док у вези са д долази до колебања јотованих и нејотованих облика (Остојић 1976: 121, 122).

${ }^{22}$ Код Његоша су обичније јотоване варијанте, мада се веома често јављају и нејотоване форме (Вушовић 1930: 24).

${ }^{23}$ Упор., Стевановић 1933-1934: 21, 35-36; Милетић 1940: 345; Пешикан 1965: 110; Вушовић 1927: 15, 16, 25.

${ }^{24}$ Овдје доминирају јотовани облици (УП. Стојановић 2011). 


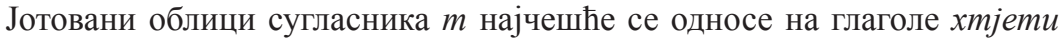
(овај глагол се користи и у нејотованој форми, мада су ти примјери рјеђи), тјерати и летјети и изведенице од њих. Нејотовани примјери су већином писани са јатом изузев једног примјера са $е$ [захтела (Г. 1837: 114)]. Нејотоване примјере од коријена хоть- срећемо углавном се $e$ [хотеле (Г. 1835: 121), хотело (Г. 1835: 122), хотели (Г. 1836: 124)]. Ријетки су примјери са јатом и са $u$, а односе се на радни глаголски придјев [хотъо (Г. 1837: 95) хотіо (Г. 1836: 109)]. У позицији $\partial+j e<z$ јављају се подједнако јотоване и нејотоване форме. Нејотовани облици писани су већином са $\not{b}$. Забиљежили смо само два примјера са $e$, и то оба из пјесме Симе Милутиновића Сарајлије Одлазак Карађорђія из свога отечества (Грлица 1835: 120, 121): дечица (Г. 1835: 121), деие (Г. 1835: 121).

Овдје је важно поменути и Милаковићево запажање дато у издању из 1839. године у одјељку гдје описује житеље Дубровника. „Дубровчани су Срби, кои говоре наръчіємъ Херцеговачкимъ; но разликую се у говору одъ Херцеговаца неколико, особито у изговараню писмена ћ” (Милаковић 1839: $44,45) .{ }^{25}$ Ту тврдњу Милаковић даље илуструје примјерима и наводи упоредо облике типичне за Дубровчане са $\partial z$ и $\partial я$ и оне карактеристичне за Херцеговце са Ђе и Ђа: дъдъ (м. Ђедъ), дъверъ (м. Ђеверъ), дъвойка (м. Ђевойка), дъияа (м. Ђеиа), дяво (м. Ђаво), дякъ (м. Ђакъ), дяконъ (м. Ђаконъ).

Будући да у свих пет издања Грлице биљежимо паралелну употребу јотованих и нејотованих форми, можемо закључити да ни сам Милаковић није био сигуран којој варијанти треба дати предност. Могуће да је додатну дилему уносило и то што ни Вук није био досљедан кад је у питању јекавско јотовање дентала $\partial$ и $m$. Већ смо поменули да је наш велики реформатор тек 1839. напустио јотоване облике дентала $\partial$ и $m$ испред је посталог од кратког јата али су ипак у Пјеснарици и у Писменищи потврђени и нејотовани облици (Пецо 1965: 191).

3.7. Различите рефлексе кратког јата срећемо у вези са глаголом видјети, који се у Грлищи појављује са:

а) једносложним рефлексом јата и оствареним јотовањем (које смо већ навели и којих је највише);

б) неоствареним јотовањем и графијском ознаком $\partial z$ : видъx (Г. 1835: 67), видъти (Г. 1838: 90), видъти (Г. 1839: 119);

${ }^{25}$ Морамо истаћи да се нисмо придржавали пагинације дате у издањима Грлице већ смо нумерисање страна започињали од стране на којој је дат садржај. 
в) са рефлексом $u^{26}:$ видићешъ (Г. 1837: 103), видићешъ (Г. 1837: 118), видићешъ (Г. 1837: 118), видити (Г. 1837: 116), видити (Г. 1838: 29), видиће се (Г. 1838: 29), видити (Г. 1839: 96, 98, 102).

г) и са іє: видієти (Г. 1835: 59), видієли (Г. 1835: 63, 81), видієтъ (Г. 1836: 64), видієше (Г. 1836: 86), видієти (Г. 1839: 119).

Овакви облици присутни су и код Његоша (Маројевић 2002: 45), као и у Паштровским исправама (Стојановић 2011: 120), а у науци су различито објашњавани. ${ }^{27}$

3.8. Прилози који садрже партикулу де/дъ (партикула примарно писана са -e, али се касније раширила и уопштила форма са јатом $)^{28}$ у Грлици су неуједначено писани. Најчешће срећемо јотоване форме, потом облике са јатом (који су нарочито фреквентни у посљедња два издања) и ријетке примјере са е и $u$ :

Ђе (Г. 1835: 2, 128), негђе (Г. 1835: 40), ниђе (Г. 1835: 126), Ђе (Г. 1836: 38, 93), Ђено (Г. 1836: 88), негће (Г. 1836: 55, 97), нигће (Г. 1836: 86), Ђе (Г. 1837: 40, 124), Ђеће (Г. 1837: 69), Ђегођ (Г. 1837: 53), ниђе (Г. 1837: 76), гђе (Г. 1837: 117), неђе (Г. 1837: 92), Ђегођ (Г. 1837: 132), Ђе (Г. 1838: 101, 118), неђе (Г. 1838: 112), Һе (Г. 1839: 37), овђе (Г. 1835: 40), онђе (Г. 1835: 105), ђегоде (Г. 1835: 108), Овђе (39);

гдъ (Г. 1836: 119), гдъ (Г. 1837: 96), гдъито (Г. 1838: 69), гдъкоє (Г. 1838: 2), гдъ (Г. 1838: 91), гдъкоя (Г. 1838: 65), игдъ (Г. 1838: 70), гдъгдъ (Г. 1838: 73), ондъ (Г. 1838: 90), гдъкой (Г. 1839: 83), гдъ (Г. 1839: 56, 84), гдъгдъ (Г. 1839: 79);

овде (Г. 1839: 94, 96);

гди (Г. 1839: 96, 105) $)^{29}$.

Професор Остојић у језику Петра I наводи само јотоване форме ових прилога (Остојић 1976: 82). Код Његоша у прилозима за мјесто на -дъ јављају се примјери са $e$, али је већином је - овдје, овђен (Вушовић 1930: 12)... „Исто је тако $e$ (од в) било и у прилошким облицима, свуд [...] Али су ипак чешћи облици: Ђе гође...” (Вушовић 1930: 12). У Паштровским исправама се среће једино прилог гдје, који је различито писан (Стојановић 2011: 120), мада у

${ }^{26}$ Глаголе видити, волити, мрзити, сједити итд., Вук је третирао као „икавизме и у херцеговачком и у сремачком, тј. и у ијекавском и у екавском наречју (иако они то нису, нити је у њих $u$, место некадашњег $b$, чисто гласовног, већ више морфолошког карактера, добивено под утицајем системе, према облицима презентске основе)" (Стевановић 1965: 216). У нашем корпусу такви су примјери сљедећих глагола: лебдили (Г. 1837: 114), живити (Г. 1837: 106), преживити (Г. 1839: 112), претрпила (Г. 1839: 112), живити (Г. 1838: 63, 74), живило(а) (Г. 1839: 37, 69).

${ }^{27}$ Вушовић за двосложно ије у глаголу видјети каже да није особина црногорских говора, али појашњава да се у неким босанским дијалектима може чути „дуљење кратког $b$ ” у сличним примјерима (Вушовић 1930: 10). Маројевић у раду Реконструкиија рефлекса јата у критичком издағу Горског вијенца каже: „Ми смо склони да све тзв. хиперијекавске облике третирамо као дијалекатске архаизме, позајмљене или из народних говора или из народних пјесама". Он се позива и на мишљење Решетара који је из хиперијекавских облика искључивао глагол видијети, сматрајући га особином неких црногорских говора (Маројевић 2002: 46).

${ }^{28}$ Стојановић 2011: 120.

${ }^{29}$ Сви наведени примјери са $e$ и са $u$ су из приповијетке Каллу Георгија Николајевића. 
паштровским говорима преовладавају јотовани облици (Јовановић 2005: 227). Према томе, и језик Грлице се подудара са стањем у језику наведених писаца и говора јер и у овом алманаху доминирају јотовани облици. Варијанте са $e$ и $u$ јављају се у текстовима Г. Николајевића, док су облици са јатом писани у посљедњим издањима и ту јат вјероватно има само ортографско-историјску функцију.

3.9. Јекавско јотовање сугласника $c$ и з забиљежено је касније у односу на јотовање сугласника $m$ и $\partial$. „Осим тога, ова је појава и лексички и територијално ограниченија, а у свим дијалектима вршила се са мање доследности" (Стојановић 2005: 121). У цетињском алманаху у скоро свим примјерима које смо ексцерпирали графијски сегмент $c \hat{b}$ означава рефлекс кратког jaтa послије $c$ :

сусъство (Г. 1835: 54), съверну (Г. 1835: 70), сусъдством (Г. 1835: 71), състъ (Г. 1835: 91), бесъдила (Г. 1835: 108), сътовала (Г. 1835: 109), съдіо (Г. 1836: 53), бесъдіо (Г. 1836: 76), съли (Г. 1836: 96), съда (Г. 1837: 78), съвера (Г. 1837: 100), осъти (Г. 1837: 110), предсъдавао (Г. 1838: 57), посъкао (Г. 1838: 106), бесъђаху (Г. 1838: 109), бесъдила (Г. 1838: 109), Осътити (Г. 1839: 19), съверне (Г. 1839: 26), сусъдъ (Г. 1839: 47), пресъћи (Г. 1839: 62), съдити (Г. 1839: 68), съвероистоку (Г. 1839: 70, 75), съверозападу (Г. 1839: 75), посъћивао (Г. 1839: 100), засъли (Г. 1839: 121).

Графематска ознака $i \epsilon$ углавном означава рефлекс дугог јата послије $c{ }^{30}$ Међутим, забиљежили смо и примјере са $c \vec{b}$ које означава рефлекс дугог jaтa послије $c,{ }^{31}$ као и неколико примјера са $c е$ које је означавало рефлекс кратког jaтa послије c. ${ }^{32}$ Секвенца $c b$ писана је и у мушком роду радног глаголског придјева глагола сјести [czo (Г. 1836: 32), Съo (Г. 1837: 33) $]^{33}$. С обзиром на све наведено, можемо констатовати да у нашем корпусу нема графијске потврде за јекавско јотовање фрикатива $c$.

Као што смо већ поменули ни Ћупић не наводи примјере јекавског јотовања сугласника $c$ и з у Грлици, иако је та гласовна алтернација забиљежена у готово свим говорима Црне Горе. ${ }^{34}$ Маројевић фонетски сегмент $c \vec{b}$ на мјесту кратког јата у Горском вијениу реконструише као щее ,, ако ријеч није

${ }^{30}$ пресієиа (Г. 1835: 82 - 2), сієкући (Г. 1835: 103), сієна (Г. 1836: 21), посієку (Г. 1836: 37), посієче (Г. 1837: 60), посієкоше (Г. 1837: 60), сієчете (Г. 1836: 47), изсієии (Г. 1837: 82), сієку (Г. 1836: 63).

${ }^{31}$ посъче (Г. 1836: 47), посъче (Г. 1837: 83), пресъку (Г. 1838: 40), съку (Г. 1839: 38), съичите (Г. 1839: 105).

${ }^{32}$ сеђаше (Г. 1837: 97), сећала (Г. 1837: 116), осетити (Г. 1839: 115).

${ }^{33}$ Радни глагоски придјев у облику м. р. од глагола са инфинитивном основом на $e$, а презентском на $u$ Вук је најчешће употребљавао у облику са слогом -је непосредно прије завршног o (виђео). Тек након Бечког договора, у т. 5 Главних правила за јужно наречје Вук предочава да гласовна вриједност некадашњег $z$ испред $о$ мора бити $u$ (Стевановић 1965: 216, 218).

${ }^{34}$ Упор.: Пешикан 1965: 110; Вуковић 1938-1939: 44-47; Милетић 1940: 136-137; Стевановић 1933: 86-88; Вушовић 1927: 16-18; Станић 1974: 67; Пижурица 1981: 86-88; Јовановић 2005: 228 . 
књишког поријекла и ако говори човјек из народа, којему такав говор служи као стилска карактеристика", у супротном ту секвенцу реконструише као сје (Маројевић 2002: 32, 33 и 35). У Паштровским исправама примјењивана су различита графијска рјешења за секвенцу с + некадашње кратко jam, с тим што у исправама из 19. вијека преовладава писање јата, што може бити утицај црквеног језика (Стојановић 2011: 121), што је слично стању у Грлици. Значи да Милаковић није одступао од ставова Вука Караџића, који за меко $c$ „није узео посебан глас у нашој азбуци јер га је сматрао дијалекатском особином" (Стевановић 1965: 216).

3.10. Нисмо пронашли ниједан примјер са з + je $<$ z. Јотовање сугласника $u$, као и јотовање фрикатива $c$ и з, забиљежено је касније у односу на до сада наведене сугласнике. „Први примјери датирају из средине 17. вијека” (Стојановић 2011: 121). У ексцерпираној грађи нисмо забиљежили ниједан примјер овог јотовања. У Грлици је јат досљедно писано након сугласника ич и групе цุв:

процвътава (Г. 1835: 116), ивътних (131), скупоиъна (Г. 1836: 67), иълуюћи (Г. 1836: 69), Цветићь (Г. 1836: 109), цвътове (Г. 1837: 134), цвътнике (Г. 1837: 136), ивнительи (Г. 1837: 137), ивътаю (Г. 1838: 65), ивътати (Г. 1838: 65), цвъта (Г. 1839: 40 гл.), иъвтаюћега (Г. 1839: 43).

Вук такође није употребљавао јотоване облике у вези са овим сугласником, већ је „херцеговачком говорном особином” сматрао „не само примјере типа Ђевојка и ћерати него и примјере типа сјести, изјести и ијепаница ” што потврђује и његов Рјечник (Пецо 1965: 195). Наиме, Вук је знао за облике типа çес и ћепаница, али „није дао право стање о употреби тих гласова у говорима Херцеговине” (Пецо 1965: 195).

3.11. „Јотовање је најкасније и најнедоследније захватило уснене сугласнике, зато је оно и територијално, а поготово лексички, најограниченије и најређе" (Стојановић 2011: 124). Ћупић у Милаковићевом језику није забиљежио јотовање лабијала. Ми смо у Грлиции пронашли неколико примјера у вези са глаголом живјети: преживлъла (Г. 1836: 118), живлъти (Г. 1837: 109), живлътъ (Г. 1838: 120). ${ }^{35}$ Интересантно је што су прва два примјера потврђена код јединог сарадника Грлице који није био ијекавац по рођењу, већ екавац. Значи, могли бисмо закључити да јекавско јотовање лабијала у Грлици одступа од стања у говорима Црне Горе, ${ }^{36}$ а да се дјелимично подудара

${ }^{35}$ Прва два примјера су пронађена у приповијеткама Георгија Николајевића, које су у ствари преводи са њемачког, а трећи примјер је из народне поезије (Шуковић 1980: 44-52).

${ }^{36}$ Ћупић у раду Јекавско јотовање лабијала у говорима Црне Горе каже да је та гласовна алтернација потврђена у свим говорима Црне Горе изузев Мрковића (Ћупић 1981: 62). Међутим, ни у говору Паштровића није забиљежено јотовање секвенци лабијал $+j$ (Јовановић 2005: 230-232). У језику Петра I дијалекатско јотовање лабијала је дјелимично остварено (Остојић 1976: 119). Вушовић код Његоша биљежи само један примјер јотовања лабијала пљеном (Ву- 
са Вуковим ставовима у вези са овом појавом. Наиме, Вук је био недосљедан у вези са овом појавом. Једино је глаголе с вриједношћу некадашњег гласа $z$ у основи инфинитива и било којим усненим сугласником непосредно пред тим наставком узео у облику с извршеним јотовањем (сврбљети, живљети), у осталим случајевима такве облике је сматрао дијалекатским и нема их у његовом језику (Стевановић 1965: 218, 219).

4.1. Кад је у питању рефлекс јата иза сугласника $p$, осврнућемо се на писање континуаната кратког јата иза $p$ и на писање дугог јата у позицији сугласник $+p$ (гдје је данас уопштено $e$ ).

У позицији кад се $p$ нађе на почетку ријечи или иза вокала а иза њега слиједи кратко jam у Милаковићевој Грлиичи јављају се примјери са јатом (најчешће и примјери су из посљедња три издања) и са $e$ (нешто рјеђе):

изгорвло (Г. 1837: 71), ръчник (Г. 1839: 55), ръшителносћу (Г. 1837: 47), остаръла (Г. 1838: 108); искоренявала (Г. 1837: 96), ређи (Г. 1838: 46), укоренило (Г. 1838: 70)37.

Будући да jam у посљедњим издањима има углавном ортографско-историјску функцију и да је вјероватно писан под утицајем рускословенског, то нам не може дати довољно могућности да одредимо гласовну вриједност jaта у овој позицији. Додатно отежавајућу околност представља и језик старијих писаца код којих се напоредо јављају варијанте са је и $е$. Професор Јовановић истиче да је „питање развоја рефлекса кратког јата иза сонанта $p$ у црногорским говорима у којима је основно правило кратко $\mathrm{b}>$ је знатно еволуирало до те мјере да се други сонант $j$ у сусједству са првим $j$ све теже реализује (Јовановић 2011: 104). Мада, он појашњава да је „секвенца рје као супституент jaта у прошлости била много фреквентнија” што свједочи и „њена употреба, напоредо са ре, у језику писаца Петра I Петровића Његоша, Петра II Петровића Његоша и Стефана Митрова Љубише" (Јовановић 2011: 105).

Занимљив примјер са јатом налазимо код Милаковића у издању из 1838. године: горвречена (Г. 1838: 73, 78).

Прилог горе потврђен је у раличитим облицима у језику старијих писаца са ијекавског подручја као и у неким говорима садашње Црне Горе (Уп. Јовановић 2011: 105). Варијанта са је потврђена је у језику Његоша (Вушовић 1930: 11) и владике Даниле (Младеновић 1973: 28).

шовић 1930: 24), у Паштровским исправама забиљежено је десет примјера јотовања, лабијала (Стојановић 2011: 125). Упор. Стевановић 1933-1934: 36 и 37; Милетић 1940: 346; Пешикан 1965: 108; Вуковић 1938-1939: 47; Пецо 1964: 64-66.

${ }^{37}$ Ови екавизми забиљежени су код Г. Николајевића, Д. Милаковића и у народној пјесми Хайдукованъ... (Шуковић 1980: 49, 50, 51). 
4.2. У позицији сугласник $+p+z$ у првом цетињском алманаху јављају се облици са јатом (рјеђе) и облици са вокалом $е$ (нешто чешће):

кръпост (Г. 1835: 57), кръпко (Г. 1837: 76), кръпкогъ (Г. 1837: 124),

пређепоменутога (Г. 1835: 65), грехота (Г. 1835: 98), брегова (Г. 1837: 42), пренебрегнути (Г. 1837: 46), сретаме (Г. 1838: 100), стрепимъ (Г. 1839: 95), препровели (Г. 1839: 111).

Облике типа грјехота, грјешан Вук С. Караџић је писао са је, а проф. Остојић каже да се „спорадично јављају у покојем црногорском говору” (Јовановић 2011: 106). Лексему крепост која се у Грлици јавља са јатом Вушовић код Његоша биљежи са екавским рефлексом (Вушовић 1930: 11). Проф. Јовановић тврди да су у новије вријеме облици са je „потпуно уступили мјесто екавским” (Јовановић 2011: 106). „Свједочанство о ранијем постојању секвенце рје данас је више језик неког старијег писца него грађа из савремених говора" (Јовановић 2011: 107).

4.3. Именицу стар(j)ешина забиљежили смо свега два пута и то писану са јатом:

старвиини (Г. 1837: 80), старвиине (Г. 1837: 37).

Проф. Стојановић, поред устаљенијех облика са $е$, у Паштровским исправама наводи и један примјер писан са јатом. Код Његоша је ова лексема потврђена са секвенцом је (Вушовић 1930: 11), а у језику Петра I писана је са јатом и са е (Остојић 1976: 88). Проф. Остојић тврди да графија често не даје довољно могућности да се одреди гласовна вриједност јата. „Судећи према стању у савременим староцрногорским говорима и говорима западне и источне Црне Горе, а они у овом погледу не показују уједначеност, наведене примјере у језику Петра I треба посматрати као екавске, уколико су написани словом $e$, као јекавске са $z$ и ијекавске са словном комбинацијом ие" (Остојић 1976: 88).

\section{5. СЕКУНДАРНО JАТ}

5.1. Секундарни рефлекс јата биљежимо у ријечи грчког поријекла манастир (која се јавља и са ие и са $u$ ) и у романизму бригадир:

манастіср (Г. 1835: 54, 55, 57, 58, 66), манстісру (Г. 1835: 55),

манастир (Г. 1835: 46, 62), манастира (Г. 1835: 98, 99), манастир (Г. 1836: 51, 56), манастирска (Г. 1836: 51), манастиру (Г. 1836: 72), монастыра (Г. 1838: 48, 71), манастырь (Г. 1838: 84);

Бригадієра (Г. 1837: 37).

Без секундарног јата срећемо примјере: кавалерима (Г. 1838: 84), Oфицииръ (Г. 1839: 94).

Занимљиво је да Ћупић код Милаковића лексему манастир најчешће биљежи у облику манастієр, тј. са секундарним рефлексом јата (Ћупић 
1982: 273). Међутим, наши примјери показују да је друга варијанта (манастир) ипак много фреквентнија. Већина забиљежених примјера писаних без секундарног јата је из Милаковићевих текстова изузев неколика пронађена код Његоша (Г. 1835: 62 и Г. 1835: 98, 99). Код Петра I секундарни рефлекс јата јавља се само у неколико примјера и то у именицама манастир и бригадир (Остојић 1976: 90), а Вушовић код Његоша наводи само један примјер овог типа - талијера (Вушовић 1980: 12). У Паштровским исправама примјери овог типа, углавном романизми, се готово искључиво јављају у форми са uje (Стојановић 2011: 126).

5.2. Код појединих итеративних глагола са суфиксом -ива, такође наилазимо на „призвук ијекавштине” (Јовановић 2011: 133):

салієвасе (Г. 1835: 42), пролієва (Г. 1836: 67, 98), пролієва (Г. 1837: 57).

Код глагола проливати срећемо и облике са $u$ и један примјер са јатом: пролива (Г. 1838: 111), пролива (Г. 1837: 98), прольваме (Г. 1835: 115).

„Конкуренцију привидних ијекавско-икавских ликова (-)лити / (-)лијевати Правопис из 1960. године је ријешио прихватањем обје форме, а Вук Караџић је односе улијѐвати-улијеваิм, уле́вати-уливаิм схватао као ијекавско-екавско-икавски однос" (Јовановић 2011: 133). Слични примјери потврђени су у појединим дијалектима (Уп. Милетић 1940: 252, 253; Стевановић 1931-934: 26, 27; Ћупић 1977: 26; Вушовић 1927: 10; Станић 1974: 75).

5.3. Именица болест јавља се два пута код Његоша у приповијеци Житіс Мрђена Несретниковића, гдје је различито писана - са екавским рефлексом e и са iє: болест (Г. 1837: 74), болієсти (Г. 1837: 88). Иначе се код Његоша ова именица јавља са екавским и ијекавским рефлексом (Стевановић 1983: 45). У издању из 1838. У календарском дијелу писана је са $e$ : биће болестій (Г. 1838: 19).

6. Закључак: У прва три издања Грлиие рефлекс дугог јата већином је означаван секвенцом $i \epsilon$, уз извјесна одступања. У посљедња два издања обиљежавање дугог јата је неуједначено - у издању из 1838. на мјесту некадашњег дугог jam пишу се секвенца $i \epsilon$, вокал $e$, или веома често $b$. У издању из 1839. године као графијска рјешења срећемо јат и вокал $e$. Оваква неуједначеност највјероватније је условљена утицајем језика цркве (нарочито у посљедња два издања) и дијалекатске базе, а може бити условљена и утицајем различитих „стилова”.

Гласовну вриједност континуаната кратког јата отежава то што у Грлищи нису коришћене посебне графеме за означавање фонема $s$, , исти начин означаване секвенце ле, не и љье, юе (ль, нъ). Слично је и у језику Петра I (Остојић 1976: 122), као и у Паштровским исправама у којима такође 
нису постојале посебне графеме за $љ$ и ю (Стојановић 2011: 112). У нашем корпусу ситуацију отежава и то што се у посљедња два издања јат писало и на мјесту некадашњег дугог јата.

У Милаковићевој Грлици као континуанти старог јата јављају се и вокали $e$ и $u$, што је условљено одређеним фонетским позицијама у којима је овај рефлекс уобичајен у већини (и)јекавских говора, као и одређеним аналошким укрштањима.

\section{ЛИТЕРАТУРА}

Барјактаровић 1965: Д. Барјактаровић, Питање јата код Вука Караџића, Анали Филолошког факултета, V, 15-26.

Белић 2006: А. Белић, Историја српског језика, Четврти том, Београд: Завод за уџбенике и наставна средства.

Вујовић 1969: Л. Вујовић, Мрковићки дијалекат, Српски дијалектолошки зборник, XVIII, 73-401.

Вушовић 1927: Д. Вушовић, Диалект Источне Херцеговине, Српски дијалектолошки зборник, III, 1-71.

Вушовић 1930: Д. Вушовић, Прилози проучавању Његошева језика, Јужнословенски филолог, IX, 93-196.

Ђукић 1951: Т.Ђукић, Преглед књижевног рада Црне Горе: од Василија Петровића Његоша до 1918. године, Цетиње: Народна књига.

Јовановић 2005: М. Јовановић, Говор Паштровића, Подгорица: Универзитет Црне Горе.

Јовановић 2011: М. Јовановић, Полугласници и јат у ирногорским говорима, Подгорица: ЦАНУ.

Маројевић 2002: Р. Маројевић, Реконструкција рефлекса јата у критичком издању Горског вијенца, Српски језик, VII, 5-67.

Мартиновић 1965: Н. С. Мартиновић, Развитак штампе и штампарства у Црној Гори (1493-1945), Београд: Југословенски институт за новинарство.

Милетић 1940: Б. Милетић, Црмнички говор, Српски дијалектолошки зборник, IX, 239-255.

Милановић 2014: А. Милановић, Језик Јована Суботића, Београд: Филолошки факултет.

Младеновић 1973: А. Младеновић, Језик Владике Данила, Нови Сад: Матица српска. 
Младеновић 1983: А. Младеновић, Екавизам 'несам' и сл. у језику неких српских писаца средине и друге половине XIX века, Научни састанак слависта у Вукове дане, 13/2, 57-67.

Остојић 1976: Б. Остојић, Језик Петра I Петровића, Титоград: ЦАНУ.

Пецо 1965: А. Пецо, Фонетика Вукова језика према фонетици ијекавске Херцеговине, Анали Филолошког факултета, V, 191-199.

Пешикан 1965: М. Пешикан, Староцрногорски, средњекатунски и љешански говори, Српски дијалектолошки зборник, XV, 104-111.

Стевановић 1933-1934: М. Стевановић, Источноцрногорски дијалекат, Јужнословенски филолог, ХІІІ, 1-129.

Стевановић 1965: М. Стевановић, Карактер дијалектизама у језику Вука Караџића, Анали Филолошког факултета, V, 209-227.

Стојановић 2007: Ј. Стојановић, Континуанти вокала јат у историји српског књижевног језика, Научни састанак слависта у Вукове дане, 37/1, 305-317.

Стојановић 2011: Ј. Стојановић, Континуанти вокала јат у Паштровским исправама, Гласник Одјељења умјетности, Књига 29, Подгорица: ЦАНУ, 103-129.

Ћупић 1977: Д. Ћупић, Јекавско јотовање лабијала у говорима Црне Горе, Научни састанак слависта у Вукове дане, 7, 57-63.

Ћупић 1978: Д. Ћупић, Језик Димитрија Милаковића у „Грлици” - првом црногорском књижевном алманаху (1835-1839), Научни састанак слависта у Вукове дане, 8/1, 267-283.

Шуковић 1980: Р. Шуковић, Црногорски алманаси и календари (1835-1914), Кьижевноисторијска обрада са библиографијом, Цетиње: Централна народна библиотека СР Црне Горе „Ђурђе Црнојевић”.

Шуковић 1987: Р. Шуковић, Примјена Вукове језичке и правописне норме у црногорској штампи XIX вијека, Зборник радова са научног скупа Вук Ст. Караиић и Црна Гора, Титоград: ЦАНУ, 37-47.

Сајт Српске православне цркве, Митрополија дабробосанска: http://www. mitropolijadabrobosanska.org/georgijenikolajevic.html, посјећено 7. 6. 2015 . 


\section{REFLEXY VOCAL § IN LITERARY-SCIENTIFIC ALMANAC "GRLICA” FROM 1835 TO 1839 ('TURTLE DOVE” FROM 1835 TO 1839)}

\section{Summary}

This paper will analyze vocals $z$ (reflexy long and short $\mathrm{b}$ ) in literary-scientific almanac "Grlica" from 1835 to 1839 (Turtle Dove" from 1835 to 1839). This will entail making historical and linguistic comparasions, and the results of this voice alterations in the given corpus will be compared to the state of the Sebian language reformed by Vuk Karadzic, as well as dialects of the Serbian language spoken in the areas from which the almanac's coauthors originated. 